\title{
Editorial: The past as prologue to the future: The times, they've been a-changin'
}

\author{
DANTE CICCHETTI $^{a}$ AND L. ALAN SROUFE ${ }^{b}$ \\ ${ }^{a}$ Mt. Hope Family Center, University of Rochester; and ${ }^{b}$ Institute of Child Development, \\ University of Minnesota
}

"[A]n overview of the past suggests that today's investigators are as much determined by history as they are makers of it." (Cairns, 1983, p. 90)

As we move forward in the new millennium, we are all provided with an opportunity to look back at scientific events, advances, and disappointments that have occurred over the last century and that have brought us to our current state of knowledge in the field of developmental psychopathology. As we reflect on historical events in the context of the future that awaits us, we also are provided with a rare window for examining issues that are likely to be salient in the next century. This crossroads between the past and the future can present a venue for reflection, creativity, and prognostication regarding challenges and opportunities the future may hold. It is with this perspective in mind that we invited a distinguished group of scholars to contribute papers to this Special Issue. Our goal was to seize upon this historical occasion to publish a Spe-

Our collaboration on this manuscript and Special Issue was facilitated, in part, by a grant from the National Institute of Mental Health (45027); a grant jointly funded by the National Institute of Mental Health (54643) and the Administration for Children, Youth and Families; and grants from the Spunk Fund, Inc., to Dante Cicchetti, and a grant from the National Institute of Mental Health (40864) to L. Alan Sroufe.

Address correspondence and reprint requests to: Dante Cicchetti, PhD, Mt. Hope Family Center, University of Rochester, 187 Edinburgh Street, Rochester, NY, 14608 or L. Alan Sroufe, PhD, William Harris Professor, Institute of Child Development, University of Minnesota, 51 East River Road, Minneapolis, MN 55455. cial Issue of Development and Psychopathology that would challenge us, as a field, to grapple with the past and, simultaneously, look toward the future. This Special Issue represents an important opportunity for taking stock, and for assessing progress in our young discipline.

In a recent editorial published in The New England Journal of Medicine (The Editors, 2000), the most important developments of the past 1000 years that altered the face of clinical medicine were chosen. Included among the editors' selections for the most important medical developments of the past millennium were the elucidation of human anatomy and physiology; the discovery of cells and their substructures; the explication of the chemistry of life; the discovery of the relation of microbes to disease; the articulation of inheritance and genetics; knowledge of the immune system; the emergence of body imaging; and the development of molecular pharmacotherapy. Despite the astounding medical developments that have occurred over the past 1000 years, it is critical to remember that "none... was an isolated discovery or event; instead, each was a series of notable steps ... along a path that led to a crucial body of knowledge in a particular area" (The Editors, p. 42). In point of fact, this is the way that most progress occurs in the journey toward scientific discovery across all disciplines.

During the course of the past several decades, developmental psychopathology has emerged as a new science that is the product 
of an integration of various disciplines, the efforts of which had been previously distinct and separate (Cicchetti, 1984b, 1990). The field of developmental psychopathology owes its ascendance and coalescence to a variety of disciplines. These include cultural anthropology; embryology; epidemiology; genetics; the neurosciences; philosophy; psychiatry; psychoanalysis; clinical, developmental, and experimental psychology; and sociology (Cicchetti, 1990). Just as is the case in tracing the pathways to discovery in clinical medicine, the influences of these diverse disciplines on the field of developmental psychopathology illustrate the manner in which advances in our knowledge of developmental processes and within particular scientific domains mutually inform each other.

Theorists and researchers in the field of developmental psychopathology seek to unify, within a life-span framework, the many contributions to the study of individuals at high risk for developing mental disorders and those who have already manifested such disorders. Developmental psychopathologists strive to engage in a comprehensive evaluation of biological, psychological, social, and cultural processes and to ascertain how these multiple levels of analysis may influence individual differences, the continuity or discontinuity of adaptive or maladaptive behavioral patterns, and the pathways by which the same developmental outcomes may be achieved. In a discussion of the importance of basic and applied research, and of a multidomain and interdisciplinary perspective for the field of neuroscience, Miller (1995) enunciated the view that "all of the different specialties — ranging from the basic to the applied and from the biological to the social and cultural-are needed to advance our common goal of better understanding human behavior" (p. 910).

It is our conviction that the principles of developmental psychopathology provide a much needed conceptual scaffolding for facilitating this multidisciplinary integration, as well as for fostering an increased synergy among basic research, the development of preventive interventions, and the implementation of treatment programs. Rather than competing with existing theories and facts, the developmental psychopathology perspective provides a broad, integrative framework within which the contributions of separate disciplines can be fully realized in the broader context of understanding individual development and functioning.

Indeed, during the 3-plus decades since the launching of the schizophrenia high-risk projects (Garmezy \& Streitman, 1974), the 26 years since the publication of Achenbach's (1974) first text, the 17 years since the publication of the Rutter and Garmezy (1983) chapter in the Handbook of Child Psychology, the 16 years since the Special Issue of Child Development (Cicchetti, 1984a), and even the 12 years since the first annual Rochester Symposium on Developmental Psychopathology (Cicchetti, 1989) and the first issue of Development and Psychopathology, all markers of the emergence of this field, substantial progress has occurred. The 20 previous Special Issues of Development and Psychopathology provide testimony to the growth that the discipline of developmental psychopathology has witnessed in a relatively short period of time. Indeed, major advances have occurred in understanding the complexity of causality, the interaction of risk and protective factors, the heterogeneity of disorder, and the importance of developmental processes and mechanisms.

It is now widely understood that singular, linear cause will rarely obtain (Reese \& Overton, 1970; Sameroff \& Chandler, 1975). Individual risk factors seldom are powerful, and when they are it is likely that it is because they are surrogates for multiple influences. Much more often, adequate prediction of either disturbance or resilience requires considering multiple risks and protective factors and their interplay. Moreover, the consequences of any "risk" factor depends on a myriad of other aspects embedded in the developmental context. For example, Lynch and Cicchetti (1998) reported that impoverished children residing in communities high in violence fare far worse that those living in communities that are less violent. Even abused and neglected children, who typically evidence an array of difficulties in addition to their maltreatment histories, differed depending on the level of community violence present in their 
lives, with maltreated children who lived in settings high in community violence exhibiting the most difficulties.

Thus, a particular condition may not pose risk in the context of another "protective" condition. To cite one dramatic example, Suomi (in press) has shown that a defect in the serotonin transporter gene conveys no detectable liability (e.g., impulsiveness, distractibility) for rhesus monkeys reared by nurturant foster mothers; in fact, such animals become leaders of the group. Also noteworthy, the same condition may serve as a risk or protective factor for different outcomes (Cicchetti \& Aber, 1986; Luthar, Cicchetti, \& Becker, in press; Stouthamer-Loeber, Loeber, Farrington, Zhang, van Kammen, \& Maguin, 1993). For example, male gender, a risk factor for conduct disorders, could be considered a protective factor for anorexia. Additionally, Baldwin, Baldwin, and Cole (1990) found that successful high-risk families were found to be more restrictive and controlling in their parenting than were successful low-risk families. Thus, controlling parenting may be a risk factor for one group and a protective factor for another group of families.

These examples also illustrate the probabilistic rather than causal status of risk factors. For example, the female gender does not likely in and of itself cause anorexia. Being female is a marker for certain cultural and/or contextual processes that constitute a cause for the disorder (see Kraemer, Kazdin, Offord, Vessler, Jensen, \& Kupfer, 1997, for a discussion of the distinction among correlates, risk factors, markers, and causal risk factors).

Concepts of pathways, multifinality and equifinality, now are prominent in the field (Cicchetti \& Rogosch, 1996; Sroufe, 1989), having been in use in biology (von Bertalanffy, 1968; Mayr, 1964) but not even in the vocabulary of psychopathologists 30 years ago. It is now common knowledge that the same risk factors may be associated with different outcomes (i.e., multifinality) and that subgroups of individuals manifesting similar problems arrived at them from different beginnings (i.e., equifinality). This knowledge and understanding has proven to be critical, both because it may ultimately help to bring about important refinements in the diagnostic classification of mental disturbances and because it so strongly calls attention to the need for process-oriented studies. The question that has come to the fore now is no longer "What is the antecedent of X?" Instead, investigators now ask, "What are the factors that initiate and maintain individuals on pathways probabilistically associated with $\mathrm{X}$ and a family of related outcomes?" and "What differentiates those progressing to $\mathrm{X}$ from those progressing to $\mathrm{Y}$ and those being free from maladaptation or handicapping condition?"

Furthermore, comprehending the factors contributing to positive outcomes despite the presence of significant adversity (i.e., resilience) can help to broaden the understanding of developmental processes that may not be evident in "good enough" normative environments. Thus, for example, Cicchetti and Rogosch's (1997) finding that, over time, most maltreated children evidence at least some self-righting tendencies in the face of the extreme stressors experienced in their lives attests to the strong biological and psychological self-strivings toward resilience that all living organisms should possess (cf. Waddington, 1957). In contrast, the absence of such resilient self-strivings in a not insignificant number of maltreated children attests to the deleterious and pernicious impact that traumatic experiences can exert on the biological and psychological processes of self-organization.

This attention to diversity in origins, processes, and outcomes in understanding developmental pathways does not suggest that prediction is futile as a result of the many potential individual patterns of adaptation (Sroufe, 1989). There are constraints on how much diversity is possible, and not all outcomes are equally likely (Cicchetti \& Tucker, 1994; Sroufe, Egeland, \& Kreutzer, 1990). As researchers increasingly conceptualize and design their investigations at the outset with the differential pathway concepts of equifinality and multifinality as a foundation, we will come progressively closer to achieving the unique goals of the discipline of developmental psychopathology-to explain the de- 
velopment of individual patterns of adaptation and maladaptation (Sroufe \& Rutter, 1984).

Although process-oriented research continues to be underrepresented in the field, there are a number of notable exceptions. Moreover, there is increasing recognition of the dynamic interplay of influences over developmental time. Perhaps the most dramatic example of this is the work on experience-dependent brain development (Greenough, Black, \& Wallace, 1987). The viewpoint is now widely shared that neurobiological development and experience are mutually influencing (Cicchetti \& Tucker, 1994; Eisenberg, 1995; Nelson \& Bloom, 1997). Brain development impacts behavior, of course; however, the development of the brain itself is impacted by experience. Specifically, it has been demonstrated that social and psychological experiences can modify gene expression and brain structure, functioning, and organization. Alterations in gene expression induced by social and psychological experiences produce changes in patterns of neuronal and synaptic connections (Kandel, 1998, 1999). These changes not only contribute to the biological basis of individuality but also play a prominent role in initiating and maintaining the behavioral anomalies that are induced by social and psychological experiences.

Likewise, as we have drawn the distinction between factors that initiate pathways and factors that maintain or deflect individuals from pathways, there is a growing recognition of the role of the developing person as a processor of experience. The environment does not simply act on the child; the child selects, interprets, and impacts the environment in a dynamic way (Bergman \& Magnusson, 1997; Rutter, Dunn, Plomin, Simonoff, Pickles, Maughan, Ormel, Meyer, \& Eaves, 1997; Wachs \& Plomin, 1991).

There also has been a veritable explosion in our knowledge of developmental neurobiology, that area of neuroscience that focuses on factors regulating the development of neurons, neuronal circuitry, and complex neuronal organization systems, including the brain. In addition, advances in the field of molecular genetics (see Lander \& Weinberg, 2000) have contributed to the understanding of neurological disease, allowing scientists for the first time to understand the genetic basis of certain diseases without requiring foreknowledge of the underlying biochemical abnormalities. These accomplishments have helped to engender renewed excitement for the potential contributing role that the field of molecular genetics can make to comprehending the development of psychopathology (Plomin \& Rutter, 1998).

\section{What is Developmental Psychopathology?}

Multiple theoretical perspectives and diverse research strategies and findings have contributed to developmental psychopathology. A wide range of content areas, research disciplines, and methodologies have been germane. Risk factors (and protective factors) have been established at every level of analysis and in every domain. Various researchers have established beyond reasonable doubt that risks may be familial, biochemical, physiological, cognitive, affective, experiential, intrafamilial, socioeconomic, social, or cultural. Contributions to this field have come from every corner of the social and biological sciences.

It cannot even be said a priori that a given piece of research is or is not relevant to this field. A study with a single age group-even adults, for example-may resolve a methodological problem or reveal a new approach that leads to critical developmental studies. Likewise, a longitudinal study of children may be so poorly conceived that it sheds little light on development or psychopathology. Thus, we eschew an orthodoxy that says that some kinds of studies are in the fold of developmental psychopathology and others are not. We advocate a "big tent," multidisciplinary approach, and that is reflected in this Special Issue.

At the same time, a core identity for the field can be defined, manifest in a set of issues and perspectives, that makes it possible to set research directions (Cicchetti, 1993; Sroufe \& Rutter, 1984). Central, of course, is the emphasis given to discovering processes of development, with the goal of comprehending the emergence, progressive unfolding, and 
transformation of patterns of adaptation and maladaptation over time. Based upon this perspective, it is possible to evaluate our current understanding of psychopathology in general, as well as more particular problems of functioning. Although it is hazardous to say a particular study is or is not an example of developmental psychopathology (because one must consider the longer, more programmatic view of the research), it is possible to look at work in the field in terms of progress towards a developmental understanding. We can ask, for example, how evolved is our developmental understanding of child maltreatment, conduct problems, depression, bipolar disorder, or schizophrenia. We can examine work with regard to promoting such a developmental understanding, and we can suggest the kinds of studies that are now needed to move us towards an understanding of developmental process.

For example, it often requires a prodigious amount of work to establish a process or condition as a risk factor for maladaptation or psychopathology (Cicchetti \& Rogosch, 1999; Kraemer et al., 1997). However, even when the predictive status of a putative risk is confirmed, this represents merely the starting point of a developmental psychopathology analysis, not the end point. Establishing a risk factor does not in and of itself complete a developmental agenda in terms of delineating cause or course of mental disturbance. Whether, for example, the risk may be a familial liability, some psychosocial adversity, or a particular cognitive interpretive framework, its establishment does not resolve the developmental question. It is much more the case that such findings raise the developmental question or, perhaps, serve to focus it.

Research on the negative attributional biases in depression provides a useful example. These are well-established correlates of depression for both children and adults (see, e.g., Abramson, Seligman, \& Teasdale, 1978; Garber, Quiggle, Panak, \& Dodge, 1991; Garber \& Hilsman, 1992; Nolen-Hoeksema, Girgus, \& Seligman, 1992). Importantly, they also account for significant variance in subsequent depression, a basic requirement for establishing risk. These studies are critical and are not diminished by stating that they fall short of a complete developmental analysis. Rather, again, they reflect the starting point.

The next crucial step is to determine how such "biases" themselves originate and develop. There would be many possible answers, more than one of which likely applies to some cases. A developmental perspective does not require that experiential history be the only contributing factor. But a developmental approach does require that these attributional differences not be taken as simply given; they must be presumed to develop (see Garber \& Flynn, 1998).

A developmental analysis is progressive, with one step leading to another (e.g., Hammen, 1992). For example, longitudinal data suggest that adverse experiences alone predict depression in young children, whereas with older children the combination of adverse experience and negative attributional style is most predictive. (Negative bias did not add to predicted variance for younger children.) This implies that negative attributional style is an outgrowth of negative experience and that attributions are more involved in maintaining depression than in its origins (e.g., Teasdale \& Barnard, 1993). It is more complex than this, however, because negative attributions in fact lead to more adverse experiences and so on in a cyclical way. Exactly how (and what) experiences lead to negative attribution and the interplay of experience and attribution over time will require continued, detailed longitudinal study.

Similarly, if one demonstrates heritability of negative attributions or even a specific genetic risk, then this would start, not complete, a developmental psychopathology analysis. One needs to know how the genetic liability becomes translated into a negative attributional style in the progressive development of the child. This again would require a program of research, with one study leading to another until the developmental process was adequately described.

Developmental psychopathology refers not simply to the search for the indicators or predictors of later disturbance, though these are of interest, but also to the description of the interactive processes that lead to the emer- 
gence and guide the course of disturbed behavior. In trying to understand why some individuals react as they do, some researchers will emphasize one set of initiating and maintaining conditions, some others. Our point is that such factors must be explored in developmental studies, not simply taken as givens.

\section{Building Upon a Foundation}

Important beginnings have been made toward creating a body of information relevant to the field of developmental psychopathology. Examples will be found throughout this Special Issue. Here we highlight just a few, all of which point to the utility of "pathways" and "developmental process" concepts.

Recent research in depression has been important for highlighting two features (see, e.g., Rutter \& Sroufe, 2000; Zahn-Waxler, Klimes-Dougan, \& Slattery, 2000). First, as we discussed above, data support the proposition that different factors may be associated with the onset and the maintenance of depression. Such data not only underscore the complexity of cause but also specifically encourage research on the course of disorder along pathways. Second, work by Harrington, Rutter, and Fombonne (1996), for example, suggests that adult-onset and child-onset depression may be distinctive disorders. Others have confirmed a greater prevalence of psychosocial adversity as antecedent to childhood-onset depression (especially for boys) and maternal depression as antecedent to adolescent depression (especially for girls; see Duggal, Carlson, Sroufe, \& Egeland, in press). Interesting developmental questions result. For example, are a subset of depressed children (or adolescents) who go on to manifest depression in adulthood actually cases of early onset "adult depression"? Can such cases be distinguished by different patterns of antecedents and correlates? In other words, can different pathways of childhood depression be defined and will these prove to be more powerful in predicting adult outcome than manifest symptoms at a given age? This is the quintessential pathway question.

Likewise, pathway issues have come to the fore in the study of conduct problems. In her landmark study of the Dunedin sample, Moffitt (1993) proposed the distinction between childhood-onset ("life-course-persistent") and adolescent-onset ("adolescent-limited") conduct disorders. Stated differently, she defines two groups of adolescents who are distinguished more by pathway (history or no history of conduct problems) than by current manifest problems. Preliminary research suggests that, indeed, adolescent-onset cases are less likely to go on to adult criminality. Moreover, such findings have provoked great research interest in initiation of the early onset pathway (Campbell, Shaw, \& Gilliom, 2000; Loeber et al., 1993). Moffitt's two groups clearly manifest different correlates; however, currently there is some disagreement regarding preconduct problem antecedents. Moffitt contends that a neuropsychological deficit is a precursor of early onset conduct problems, whereas, based on prospective data beginning in infancy, others contend that psychosocial adversity precedes both conduct problems and verbal difficulties (Aguilar, Sroufe, Egeland, \& Carlson, 2000). It is, of course, possible that the roots of the "life-coursepersistent" pathways also are heterogeneous (including various combinations of psychosocial and biological factors), with results depending partly on the nature of the sample recruited. Further investigation is required, because the issues are too important for simply assuming that persistence and intractability necessarily imply an organic genesis.

A final example is the work of Patterson and his colleagues who have led the way in examining process features in the maintenance of disorder (in this case, conduct problems of boys). Their investigations (e.g., Dishion, Patterson, \& Griesler, 1994) illustrate the process by which antisocial behavior consolidates. What may be described as escalating coercive cycles between parent and child are amplified by siblings and carried forward to peers and back again to further provoke the family process. Such cross-time effects are of interest regardless of the initial roles of genes or early experiences. This work can serve as an exemplar for considering the confluence of factors in the perpetuation or alteration of other disorders as well. Patterson (personal 
communication) now proposes to extend the work by incorporating infant attachment assessments in an effort to unite certain initiating conditions with his work on maintenance. Other programmatic research of this sort from a variety of perspectives would be useful.

All of the investigators whose work was cited in this section would acknowledge that we are in the very early stages of comprehensive developmental analysis of any disorder. Still, little of this work was even in view 25 or 30 years ago. Progress has been substantial.

\section{Other Directions for Research}

In the brief comments above and in the discussions throughout this Special Issue, numerous suggestions for future research are proffered. Research in the past 3 decades has been most impressive in how it has led to more sophisticated questions and has opened up entire areas of inquiry. There is much to build upon; however, there are some key areas in which rather little work has been conducted and in which investigations are urgently needed.

The vast majority of published research has been based upon an acceptance of existing models and definitions of disturbance. This has been a reasonable scientific strategy. It has been useful to take the existing classification system, use it as a guide for research, and then revise that system in light of findings. Thus, an enormous amount of research has focused on what might be called "back end" research, a search for the correlates and antecedents of disorders as defined in the psychiatric nosological systems. There is, in turn, a paucity of "front end" research - that is, work that begins by defining early patterns of adaptation and maladaptation through developmental study, then traces coherent families of outcomes, which then become the basis for a classification system. Many have lamented the downward extension of adult concepts and categories to children (Bemporad \& Schwab, 1986; Jensen \& Hoagwood, 1997; Richters \& Cicchetti, 1993); however, we have not yet embraced the task of evolving a truly developmental system of classification.

Although such work would be a prodigious undertaking, it clearly would be worth the effort. As useful as the current nosologic scheme has been, it has some striking shortcomings, including heterogeneity of extant categories and extensive comorbidity of disorders. While benign interpretations of this problem have been offered (Angold, Costello \& Erkanli, 1999; Caron \& Rutter, 1991), comorbidity also may be the result of a fundamentally flawed diagnostic system. "Frontend" developmental psychopathology research will be important for examining the issue and, perhaps, for providing an alternative for classification.

"Front end" (i.e., prospective longitudinal) research also will be important in clarifying the role of gender in the development of psychopathology. Very little has been done here despite its obvious importance. The extremely lopsided male-female ratios in childhood conduct disorders, on the one hand, and female-male ratios for adolescent eating disorders, on the other, as well as the shift toward female predominance in depression at early adolescence, beg for developmental analysis.

It is an important start to ask, as Moffitt and Caspi (in press) have done, whether similar broad risk factors predict the same disorder for males and females. This cannot be the entire picture, however, because if the risk factors worked the same way, then a 10:1 male-female ratio in child conduct problems should not result. In the past, thorough reviews of gender research revealed that differences were not in mean values on particular variables (Maccoby \& Jacklin, 1974) but rather in patterns of correlations among variables (Block, 1979). Likewise, a key issue for the developmental psychopathology of gender will be the relative influence and differential patterning of various risk factors in combination. At least in a sample of largely motherreared children, boys seemed to be more influenced by quality of treatment and amount of chaos and stress and girls more by maternal personality, self-esteem, and relationship satisfaction (Sroufe \& Egeland, 1991). Such leads need to be followed up.

It will be even more important to investigate how the differential socialization of boys and girls interacts with risk and protective factors to produce particular outcomes. Bio- 
logical factors will, of course, be important; however, the profound gender differences in expressed pathology will not be reducible to sex chromosome differences. Key factors of socialization, including the expression of emotion, empathy, and interpersonal closeness, are certain to be important. Gender differences in containment of impulses, the nature and function of the peer group, and sources of self-esteem all will play a role. The field of developmental psychology has shed light on each of these; however, the integration of differential gender development into the field of developmental psychopathology remains to be accomplished.

In sum, as reflected in the contributions to this Special Issue, a great deal of progress has occurred in launching developmental psychopathology as a vital scientific field. Much of the momentum of developmental psychopathology has stemmed from an openness to pre-

\section{References}

Abramson, L. Y., Seligman, M. E. P., \& Teasdale, J. D., (1978). Learned helplessness in humans: Critique and reformulation. Journal of Abnormal Psychology, 87, 49-74.

Achenbach, T. (1974). Developmental psychopathology. New York: Ronald Press.

Aguilar, B., Sroufe, L. A., Egeland, B., \& Carlson, E. (2000). Distinguishing the early-onset/persistent and adolescence-onset antisocial behavior types: From birth to 16 years. Development and Psychopathology, 12, 109-132.

Angold, A., Costello, E. J., \& Erkanli, A. (1999). Comorbidity. Journal of Child Psychology and Psychiatry, 40, 57-87.

Baldwin, A., Baldwin, C., \& Cole, R. (1990). Stress-resistant families and stress-resistant children. In $\mathrm{J}$ Rolf, A. Masten, D. Cicchetti, K. Nuechterlein, \& S. Weintraub (Eds.), Risk and protective factors in the development of psychopathology (pp. 257-280). New York: Cambridge University Press.

Bemporad, J. R., \& Schwab, M. E. (1986). The DSM-III and clinical child psychiatry. In T. Millon \& G. L. Klerman (Eds.), Contemporary directions in psychopathology: Toward the DSM-IV (pp. 135-150). New York: Guilford Press.

Bergman, L., \& Magnusson, D. (1987). A person-oriented approach in research on developmental psychopathology. Development and Psychopathology, 9, 291-319.

von Bertanlanffy, L. (1968). General system theory. New York: Braziller.

Block, J. H. (1979, August). Personality development in males and females: The influence of differential socialization. Paper presented at the Master Lecture Se- existing knowledge, in combination with a willingness to question established theory and research (Cicchetti \& Richters, 1997). Moreover, the integration of methods and concepts derived from areas of endeavor that are too often isolated from each other has resulted in knowledge gains that might have been missed in the absence of cross-disciplinary dialogue. Numerous challenges lie ahead, and we must continue to examine critically the implicit as well as the explicit conceptual and scientific assumptions that exist in the field of developmental psychopathology in order to sustain our momentum and to foster new advances. We would urge, as we have done in the past (Cicchetti, 1984b, 1993; Cicchetti \& Sroufe, 1976; Sroufe, 1989, 1990, 1997; Sroufe \& Rutter, 1984), that the key to further progress requires a continued emphasis on the concept of development.

ries of the American Psychological Association, New York.

Cairns, R. B. (1983). The emergence of developmental psychology. In P. Mussen (Ed.), Handbook of child psychology (Vol. 1. pp. 41-102). New York: Wiley.

Campbell, S. B., Shaw, D. S., \& Gilliom, M. (2000). Early externalizing behavior problems: Toddlers and preschoolers at risk for later maladjustment. Development and Psychopathology, 12, 467-488.

Caron, C., \& Rutter, M. (1991) Comorbidity in child psychopathology: Concepts, issues and research strategies. Journal of Child Psychology and Psychiatry, 32, 1063-1080.

Cicchetti, D. (Ed.). (1984a). Developmental psychopathology. Chicago: University of Chicago Press.

Cicchetti, D. (1984b). The emergence of developmental psychopathology. Child Development, 55, 1-7.

Cicchetti, D. (Ed.). (1989). Rochester Symposium on Developmental Psychopathology: Vol. 1. The emergence of a discipline. Hillsdale, NJ: Erlbaum.

Cicchetti, D. (1990). An historical perspective on the discipline of developmental psychopathology. In J. Rolf, A. Masten, D. Cicchetti, K. Nuechterlein, \& S. Weintraub (Eds.), Risk and protective factors in the development of psychopathology (pp. 2-28). New York: Cambridge University Press.

Cicchetti, D. (1993). Developmental psychopathology: Reactions, reflections, projections. Developmental Review, 13, 471-502.

Cicchetti, D., \& Aber, J. L. (1986). Early precursors to later depression: An organizational perspective. In L. Lipsitt \& C. Rovee-Collier (Eds.), Advances in infancy (Vol. 4, pp. 81-137). Norwood, NJ: Ablex.

Cicchetti, D., \& Richters, J. E. (Eds.). (1997). Conceptual and scientific underpinnings of research in develop- 
mental psychopathology [Special issue]. Development and Psychopathology, 9, 189-471.

Cicchetti, D., \& Rogosch, F. A. (1996) Equifinality and multifinality in developmental psychopathology. Development and Psychopathology, 8, 597-600.

Cicchetti, D., \& Rogosch, F. A. (1997). The role of selforganization in the promotion of resilience in maltreated children. Development and Psychopathology, 9, 799-817.

Cicchetti, D., \& Rogosch, F. A. (1999). Psychopathology as risk for adolescent substance use disorders: A developmental psychopathology perspective. Journal of Clinical Child Psychology, 28, 355-365.

Cicchetti, D., \& Sroufe, L. A. (1976). The relationship between affective and cognitive development in Down's Syndrome infants. Child Development, 47, 920-929.

Cicchetti, D., \& Tucker, D. (1994). Development and self-regulatory structures of the mind. Development and Psychopathology, 6, 533-549.

Dishion, T. J., Patterson, G. R., \& Griesler, P. C. (1994). Peer adaptations in the development of antisocial behavior: A confluence model. In L. R. Huesmann (Ed.), Aggressive behavior: Current perspectives (pp. 61-95). New York: Plenum Press.

Duggal, S., Carlson, E. A., Sroufe, L. A., \& Egeland, B. (in press). Depressive symptomatology in childhood and adolescence. Development and Psychopathology.

Eisenberg, L. (1995). The social construction of the human brain. American Journal of Psychiatry, 152, $1563-1575$.

Garber, J., \& Flynn, C. (1998). Origins of the depressive cognitive style. In D. K. Routh \& R. J. DeRubeis (Eds.), The science of clinical psychology: Accomplishments and future directions (pp. 53-93). Washington, DC: American Psychological Association.

Garber, J., \& Hilsman, R. (1992). Cognitions, stress, and depression in children and adolescents. Child and Adolescent Psychiatric Clinics of North America, 1, 129-167.

Garber, J., Quiggle, N., Panak, W., \& Dodge, K. (1991). Aggression and depression in children: Comorbidity, specificity, and social cognitive processing. In D. Cicchetti \& S. L. Toth (Eds.), Rochester Symposium on Developmental Psychopathology: Vol. 2. Internalizing and externalizing expressions of dysfunction (pp. 225-264). Hillsdale, NJ: Erlbaum.

Garmezy, N., \& Streitman, S. (1974) Children at risk: Conceptual models and research methods. Schizophrenia Bulletin, 9, 55-125.

Greenough, W., Black, J., \& Wallace, C. (1987). Experience and brain development. Child Development, 58 , 539-559.

Hammen, C. (1992). Cognitive, life stress, and interpersonal approaches to a developmental psychopathology model of depression. Development and Psychopathology, 4, 189-206.

Harrington, R., Rutter, M., \& Fombonne, E. (1996). Developmental pathways in depression: Multiple meanings, antecedents, and endpoints. Development and Psychopathology, 8, 601-616.

Jensen, P. S., \& Hoagwood, K. (1997). The book of names: DSM-IV in context. Development and Psychopathology, 9, 231-249.

Kandel, E. R. (1998). A new intellectual framework for psychiatry. American Journal of Psychiatry, 155, 475-469.

Kandel, E. R. (1999). Biology and the future of psycho- analysis: A new intellectual framework for psychiatry revisited. American Journal of Psychiatry, 156, 505524.

Kraemer, H. C., Kazdin, A. E., Offord, D. R., Vessler, R. C., Jensen, P. S., \& Kupfer, D. J. (1997). Coming to terms with the terms of risk. Archives of General Psychiatry, 54, 337-343.

Lander, E. S., \& Weinberg, R. A. (2000). Genomics: Journey to the center of biology. Science, 287, 17771782.

Luthar, S. S., Cicchetti, D., \& Becker, B. (in press). The construct of resilience: A critical evaluation and guidelines for future work. Child Development.

Lynch, M., \& Cicchetti, D. (1998). An ecological-transactional analysis of children and contexts: The longitudinal interplay among child maltreatment, community violence, and children's symptomatology. Development and Psychopathology, 10, 235-257.

Maccoby, E., \& Jacklin, C. (1974). The psychology of sex differences. Stanford, CA: Stanford University Press.

Mayr, E. (1964). The evolution of living systems. Proceedings of the National Academy of Sciences, 51, 934-941.

Miller, N. E. (1995). Clinical-experimental interactions in the development of neuroscience: A primer for nonspecialists and lessons for young scientists. American Psychologist, 50, 901-911.

Moffitt, T. E. (1993). "Life-course-persistent" and "adolescence-limited" antisocial behavior: A developmental taxonomy. Psychological Review, 100, 674701.

Moffitt, T. E., \& Caspi, A. (in press). Childhood predictors differentiate life-course persistent and adolescence-limited antisocial pathways, among males and females. Development and Psychopathology.

Nelson, C. A., \& Bloom, F. E. (1997). Child development and neuroscience. Child Development, 68, 970-987.

Nolen-Hoeksema, S., Girgus, J., \& Seligman, M. (1992). Predictors and consequences of childhood depressive symptoms: A 5-year longitudinal study. Journal of Abnormal Psychology, 101, 405-422.

Plomin, R., \& Rutter, M. (1998). Child development, molecular genetics, and what to do with genes once they are found. Child Development, 69, 1221-1240.

Reese, H., \& Overton, W. (1970). Models of development and theories of development. In L. R. Goulet \& P. Baltes (Eds.), Life span developmental psychology: Research and theory (pp. 115-145). New York: Academic Press.

Richters, J. E., \& Cicchetti, D. (1993). Mark Twain meets DSM-III-R: Conduct disorder, development, and the concept of harmful dysfunction. Development and Psychopathology, 5, 5-29.

Rutter, M., Dunn, J., Plomin, R., Simonoff, E., Pickles, A., Maughan, B., Ormel, J., Meyer, J., \& Eaves, L. (1997). Integrating nature and nurture: Implications of person-environment correlations and interactions for developmental psychopathology. Development and Psychopathology, 9, 335-364.

Rutter, M., \& Garmezy, N. (1983). Developmental psychopathology. In P. Mussen (Series Ed.) \& E. M. Hetherington (Vol. Ed.), Handbook of child psychology (4th ed., Vol. 4, pp. 774-911). New York: Wiley.

Rutter, M., \& Sroufe, L. A. (2000). Developmental psychopathology: Concepts and Challenges. Development and Psychopathology, 12, 265-296.

Sameroff, A. J., \& Chandler, M. J. (1975). Reproductive risk and the continuum of caretaking casualty. In 
F. D. Horowitz (Ed.), Review of child development research (Vol. 4, pp. 187-244). Chicago: University of Chicago Press.

Sroufe, L. A. (1989). Pathways to adaptation and maladaptation: Psychopathology as developmental deviation. In D. Cicchetti (Ed.), Rochester Symposium on Developmental Psychopathology: Vol. 1. The emergence of a discipline (pp. 13-40). Hillsdale, NJ: Erlbaum.

Sroufe, L. A. (1990). Considering normal and abnormal together: The essence of developmental psychopathology. Development and Psychopathology, 2, 335347.

Sroufe, L. A. (1997). Psychopathology as an outcome of development. Development and Psychopathology, 9, 251-268.

Sroufe, L. A., \& Egeland, B. (1991). Illusion of person and environment interaction from a longitudinal study. In T. Wachs \& R. Plomin (Eds.), Conceptualization and measurement of organism-environment interaction (pp. 68-84). Washington, DC: American Psychological Association.

Sroufe, L. A., Egeland, B., \& Kreutzer, T. (1990). The fate of early experience following developmental change: Longitudinal approaches to individual adaptation in childhood. Child Development, 61, 1363-1373.

Sroufe, L. A., \& Rutter, M. (1984). The domain of devel- opmental psychopathology. Child Development, 55, $17-29$.

Stouthamer-Loeber, M., Loeber, R., Farrington, D. P., Zhang, Q., van Kammen, W., \& Maguin, E. (1993). The double edge of protective and risk factors for delinquency: Interrelations and developmental patterns. Development and Psychopathology, 5, 683-701.

Suomi, S. (in press). Parents, peers, and the process of socialization in primates. In J. Borkowski, S. Ramey, \& M. Bristol-Power (Eds.), Parenting and your child's world. Hillsdale, NJ: Erlbaum.

Teasdale, J., \& Barnard, P. (1993). Affect, cognition, and change: Remodelling depressive thought. Hove, England: Erlbaum.

The Editors. (2000). Looking back on the millennium in medicine. New England Journal of Medicine, 342, 42.

Wachs, T., \& Plomin, R. (Eds.). (1991). Conceptualization and measurement of organism-environment interaction. Washington, DC: American Psychological Association.

Wadddington, C. H. (1957). The strategy of genes. London: Allen and Unwin.

Zahn-Waxler, C., Klimes-Dougan, B., \& Slattery, M. (2000). Internalizing problems of childhood and adolescence: Progress and prospects for advances in understanding anxiety and depression. Development and Psychopathology, 12, 443-466. 